\title{
Some reflections on world and individuation in the thinking of Hans Jonas
}

Roberto Franzini Tibaldeo

\section{(2) OpenEdition}

1 Journals

Electronic version

URL: https://journals.openedition.org/alter/1903

DOI: $10.4000 /$ alter.1903

ISSN: 2558-7927

Publisher:

Association ALTER, Archives Husserl (CNRS-UMR 8547)

Printed version

Date of publication: 1 November 2019

Number of pages: 157-171

ISBN: 978-2-9550449-5-7

ISSN: $1249-8947$

Electronic reference

Roberto Franzini Tibaldeo, "Some reflections on world and individuation in the thinking of Hans Jonas", Alter [Online], 27 | 2019, Online since 22 December 2020, connection on 13 June 2021. URL: http://journals.openedition.org/alter/1903 ; DOI: https://doi.org/10.4000/alter.1903

This text was automatically generated on 13 June 2021.

Revue Alter 


\title{
Some reflections on world and individuation in the thinking of Hans Jonas
}

\author{
Roberto Franzini Tibaldeo
}

\section{Introduction}

1 In this paper I wish to address the topic of the relationship between spirit (or mind) and the cosmos (or world) from the perspective of Hans Jonas, who devoted some effort to clarifying the constitution of the phenomenal domain as being characterized by an $a$ priori correlation between world and spirit/mind. In particular, I endeavour to show how, according to Jonas, the process of individuation of life and then spirit/mind is dynamically related to a pre-individual cosmic dimension. Furthermore, I intend to address the following questions: A) How is individuality related to objective reality? In what sense does the latter generate the process of individuation? B) How can the anthropological difference be understood without simply reducing it to idealistic or naturalistic perspectives? C) Why and in what sense is metaphysics necessary in order to respond to the cosmological question?

\section{What is an individual?}

At the very beginning of the essay programmatically entitled Biological Foundations of Individuality Jonas expresses dissatisfaction with the two traditional ways of understanding individuality - namely, on the one hand, the perspective from outside, according to which matter and then space and time are to be regarded as the principium individuationis and, on the other hand, the view focusing on the individual's own form or essence. Jonas expresses a different point of view and a different methodology of enquiry: “I wish here to take a stand 'within', asking what it is to be an individual - for the individual itself; and I shall try to expound a concept which makes individuality the 
prerogative of a specific mode of existence and therefore the peculiarity of beings endowed with that mode of existing" (Jonas 1974, p 86-187). which highlights individuation as a continuous, dynamic, and to some extent paradoxical, process - a process in which even the observer as such is involved. Then he delimits the boundaries of individuality by focusing on the organic phenomenon:

My contention will be that, on the evidence penetrable to us, the proposed conditions are exhibited by organisms and organisms only, but in some measure by all organisms: that they are integral to organic being as such; and that therefore the realm of individuality, in all its grades, is coextensive with the biological realm as a whole (Jonas, 1974, p 87).

\section{Outcomes of the enquiry into individuation: ontology, purposiveness, human being}

$$
\begin{aligned}
& \text { Given these preliminary remarks, what are the outcomes of Jona } \\
& \text { individuality? I would like to draw attention to the following points. }
\end{aligned}
$$

Firstly, his enquiry aims at answering an ontological issue: What is the individuality of the living viz. organic individual? Any living being - he answers - is characterised by a relation of "needful freedom to matter" (Jonas 1966, p. 80). And he explains: "the exercise of the freedom which the living thing enjoys is rather a stern necessity. This necessity we call 'need', which obtains only where existence is unassured and identity a continual task" (Jonas 1974, p. 191). And why is this "needful freedom" endowed with ontological relevance? Precisely because it highlights with great exactness what it means for a living organism to be an individual: "the ontological individual requires, behind the continuity of form, internal identity as the subject of its existing in actu. Even 'form' itself, i.e. the very structure dynamically securing its own preservation [...], must be deemed to be in the service of that self-related identity. It is the aspect of 'need' which gets us beyond the indifference of the mere form-matter relation" (Jonas 1974, p. 195). This necessity - concludes Jonas - is the living being's "need for constant self-renewal, and thus need for the matter required in that renewal, and thus need for "world" (Jonas 1974, p. 195).

7 In other words, the (organic) individual is that freedom which needs the world in order to exist. This means that the individual's being, "suspended in possibility, is to be 
actualized by the use of the world" (Jonas 1974, p. 196). And as a broader ontological result, metabolism as the basic dynamic of the organic individual plainly evidences that being is to be understood in terms of a "polarity of being and not-being, of self and world, of freedom and necessity" (Jonas 1974, p. 196). And as regards the polarity of self and world, Jonas clarifies for instance that the "challenge of 'selfhood' qualifies everything beyond the boundaries of the organism as foreign and somehow opposite: as 'world', within which, by which, and against which it is committed to maintain itself. Without this universal counterpart of 'other', there would be no 'self" (Jonas 1974, p. 196). As a result, the living being ought to be understood in terms of a dynamics or a dialectical process of individuation.

8 Secondly, the dialectical process of organic individuality - namely, of life - evidences not only mere preservation, but also entails purposiveness or teleology. States Jonas: "Because of the metabolizing mode of this identity, need is of its very essence and it is thus with it from the beginning. But the very means evolved to serve this need, such as perception, locomotion, desire, add new kinds of need to the basic, metabolic one - and therewith new kinds of satisfaction. This dialectic too is of the essence of life" ${ }^{1}$. In other words, the individual embodies a specific mode of being, whose Sosein or distinctive condition (Jonas 1984, p. 40; Jonas 2015, p. 91) highlights a unique dynamics called purposiveness or teleology, whose full meaning has to be recovered against inadequate interpretations of the latter:

Spinoza, with the knowledge of his time, did not realize that the conatus to persevere in being can only operate as a movement that goes constantly beyond the given state of things. What, in its total effect, appears to be the maintaining of the given condition, is in fact achieved by way of a continuous moving beyond the given condition. There is an openness, a horizon, intrinsic to the very existence of the organic individual [...]. Its continuation is always more than mere preservation. Organic individuality is achieved in the face of otherness, as its own ever challenged goal, and is thus teleological (Jonas 1974, p. 197).

So, according to Jonas, the process of organic individuation is at the root of the overall purposive or teleological tendency of life, which can in some sense be referred to as evolution, although in a peculiar ontological sense (neither merely monistic-Darwinian, nor dualistic) ${ }^{2}$. All individuals share the following definition: "To be an individual means not-to-be-integrated with the world [...]. Individuality implies discontinuity" (Jonas 1974, p. 204). However, Jonas also states that "individuality itself is something that can be present in greater or smaller measure" (Jonas 1974, p. 204), commensurate with the complexity of the living beings' biological structure. As a result - concludes Jonas - shifts on this scale represent "qualitative differences of being" (Jonas 1974, p. 204).

10 The third outcome of Jonas' enquiry into individuality concerns the specificity of the human being's experience of individuation and - as we shall see shortly - the meaning of its reflective turn. Let us go back to Jonas' account of the "biological meaning of individuality" (Jonas 1974, p. 205) and briefly recall both its continuity (i.e. that any organic individual is characterised by a dialectical process of individuation) and its discontinuity (i.e. that the evolution of life evidences diverse qualitative measures of individuality). As regards animal life, Jonas states that its discontinuity and difference from other forms of organic life can be understood as follows:

The spatial gap between subject and object, which is provisionally spanned by perception, is at the same time the temporary gap between need and satisfaction that is provisionally spanned by emotion (desire) and practically overcome by 
motion. All three modes [perception, emotion, motion] express the mediacy of animal being, or the split between self and world - a qualitative widening of the split which metabolism opened first, and which is thus at the root of life. The lesser integration of the animal into its environment as compared to the plant, of which these modes of mediacy bear witness, is a measure of its greater individuality (Jonas 1974, p. 204).

11 And what about the human being? How can its specificity be understood? Jonas addresses this question through the same methodology of enquiry: like all organisms, the human being is also characterised by a dialectical dynamics of individuation (selfworld and subject-object split, means of survival and mediacy in order to bridge the split etc.); however, unlike other organisms, the process of human individuation reveals something qualitatively unique. Jonas' account of the human specificity is twofold ${ }^{3}$ : A) he highlights the human being's "image faculty" as the "further degree of mediacy" (Jonas 1966, p. 184) which distinguishes man from animals; and B) he evidences a "threshold to a further mediation", which is achieved thanks to reflection (Jonas 1966, p. 185). Both image faculty and reflection are understood through the lens of the individuation process - namely the aforementioned view from 'within', which offers a renewed ontological insight. First, the image faculty:

This new degree lies in the ideative extension of perception [...]. The new mediacy consists in the interposition of the abstracted and mentally manipulable eidos between sense and actual object, just as on the level of animal mediacy the perception of objects was interposed between the organism and its primary environment-relation. Imaging and speaking man ceases to see things directly: he sees them through the screen of representations of which he has become possessed by his own previous dealings with objects, and which are evoked by the present perceptual content, impregnating it with their symbolic charge (Jonas 1966, p. 184-185).

12 This feature - concludes Jonas - provides the human being with "an 'experience' at a remove - symbolic experience, in which the world is taken hold of without imposing its presence" (Jonas, 1966, p. 185).

13 However, "true man", viz. the human peculiarity, fully appears only thanks to reflection, which generates a radical turn in the previously analysed dynamics of subjectification (or individuation) and objectification, which characterises life as such:

The fateful freedom of objectification, which confronts the self with the potential sum total of the "other", the "world", as an indefinite realm for possible understanding and action, can and eventually must turn back, with its burden of mediacy, upon the subject itself and make it in turn the object of a relation which again takes the detour via the eidos. The "form" here involved is different in kind from those of the whole realm of outwardness, for it concerns the self's relation to all outwardness. The new dimension of reflection unfolds, where the subject of all objectification appears as such to itself and becomes objectified for a new and ever more self-mediating kind of relation. With the first asking of the question, What is man's, what is my place and part in the scheme of things ?, the self becomes engulfed in the distantness in which all things are kept by man and from which they have to be retrieved in acts of eidetic intentionality (Jonas 1966, p. 185).

So Jonas comes to the conclusion that it is "in the gulf opened by this confrontation of oneself with oneself, and in the exercise of the relation which in some way or other always has to span the gulf, that the highest elations and deepest dejections of human experience have their place" (Jonas 1966, p. 187). The dynamic of this experience is to be understood as a "continuous synthesis and integration into a total image" endowed with self-reflective significance: "Quaestio mihi factus sum, 'a question have I become 
unto me': religion, ethics, and metaphysics are attempts, never completed, to meet and answer the question within an interpretation of total reality" (Jonas 1966, p. 187).

Thus the human specificity, as with other forms of life, is explained in terms of the process of individuation. Nevertheless, it presents a unique quality - namely selfreflection - and an essentially unsurpassable ambiguity, which Jonas already explored in his earlier enquiry into late antique Gnosticism and Christianity ${ }^{4}$.

\section{The cosmological issue}

However, I believe that the human specificity underlines a further possibility of enquiry - one that is definitely relevant to the relationship between world and individuation. The very last line of the previous quote refers to the human task to meet and answer the question regarding one's own constitution "within an interpretation of total reality". In this regard, among the relevant questions are the following: How to understand the relationship between the process of individuation resulting in the human being and the sheer materiality of non-living reality? Further, what precedes matter as such? What about the origins of the cosmos? These questions pertain to the domain of metaphysics, which, according to Jonas, is one of the distinctive possibilities of human self-reflection. What does the possibility of metaphysics evidence? It reveals that the process of individuation, which stems from life's primeval act of distantiation its setting up of opposition between "self" and "world" - results in a radical enquiry into the ubi consistam of total reality and into the very reason of what exists.

It is urgent since, according to Jonas, the modern mind tends to dismiss the fruitfulness of this enquiry by providing reductive answers. Jonas does affirm many discoveries of the modern mind, such as "the passing nature of cultures and societies" (Jonas 1966, p. 266), "the discovery of Man's basic historicity" and "the ontological elaboration of the innermost temporality of his being" (Jonas 1966, p. 267), and finally the radical contingency of being and existence, since - states Jonas - "there is no necessity of there being a world at all" (Jonas 1966, p. 279; Theis 2014, p. 46). Nevertheless, he firmly resists the temptation, characteristic of the modern mind, of attempting to escape the true meaning of the metaphysical question 'Why is there something rather than nothing?' through negation, reduction etc. And consequently, Jonas does not share the modern tendency to draw nihilistic ethical conclusions, which appear to be even more dangerous and irresponsible in times of technological development (Jonas 1984). On the contrary, if correctly understood, "this unanswerable question of metaphysics should protect us from taking existence for an axiom, and its finiteness for a blemish on it or a curtailment of its right. Rather is the fact of existence the mystery of mysteries" (Jonas 1966, p. 279), and our philosophical efforts should be devoted to clarifying this issue. Indeed, according to Jonas, the mystery ought not to discourage our enquiry nor prevent it anyhow, provided that we choose the proper means of investigation. Besides, precisely such an enquiry provides clear evidence of the human being's reflective uniqueness - as previously detailed.

How does Jonas tackle the issue of enquiring into this "mystery of mysteries", which is "the fact of existence"? And how does his enquiry shed further light on the dynamics of individuation and its contribution to cosmology? 
20 We have to analyse one of Jonas' last works, namely Materie, Geist und Schöpfung: kosmologischer Befund und kosmogonische Vermutung (1988), which was translated into English under the title Matter, Mind, and Creation: Cosmological Evidence and Cosmogonic Speculation (Jonas 1996, p. 165-197). In this essay Jonas puts forward a hypothesis "for explaining the tendency of nature, beginning from structures of a lower order, to create a higher order such as we know" (Jonas 1996, p. 165). Indeed, the question is: "From what principle of progress can [the universal matter's] development - that of the whole cosmos and then especially that of the Earth up to the most subtle forms of the organic world - be explained? The riddle here is the physically improbable, antientropic direction from disorder to order (only the opposite is probable), and from the lower to the higher" (Jonas 1996, p. 166-167; see also Spinelli 2016, p. 548-549). According to Jonas, neither the concept of "cosmogonic logos or information", which is ultimately deterministic, nor the alternative statement that order derives from disorder through natural selection, are convincing (Jonas 1996, p. 167-170).

21 How to tackle the issue then? By recalling the ontological meaning of organic individuals (along with their subjectivity/inwardness and dynamics - Jonas 1996, p. 170) and highlighting its cosmological significance. Indeed, the very existence of organic individuals challenges, strictly speaking, both dualistic and materialistic interpretations, which are incapable of explaining the specificity of organic beings:

Nevertheless [states Jonas], a monistic solution to our riddle is to be sought, since the voice of subjectivity in animals and human beings did emerge from the mute vortex of matter and continues to adhere to it. It is universal matter itself which, in becoming inward, finds its voice in subjectivity. Matter's most astounding accomplishment may not be denied it in any account of Being. What appears necessary, then, for a monistic solution is an ontological revision and replenishing of the concept of "matter" beyond the external qualities abstracted from it and measured by physics; and this means, therefore, a meta-physics of the material substance of the world. In statements that are just conjectures, proposed to stimulate further reflection, I will attempt to formulate what has imposed itself on me after many decades of pondering ${ }^{5}$

22 And what about the results of this reflection? Let me try to summarise Jonas' cosmological, and then cosmogonic, line of reasoning, whose relevance to the dynamic of individuation and to the place of the human being in the world Jonas scholars have so far either not duly recognised or have tended to understand differently ${ }^{6}$ :

23 - Firstly, cosmic matter is endowed "with the possibility of eventual inwardness [i.e. subjectivity, individuation] - not an endowment with inwardness, still long in coming, and not even an endowment for inwardness in the sense of being already prepared for it" (Jonas 1996, p. 172). In other words, matter is endowed with a certain degree of potentiality. Two questions arise then: "Who (or what) 'endowed' matter in such a manner? and, What share did this 'endowment' have in the course of cosmic events? What we are raising here is the question of an initial creative will and its further efficacy" (Jonas 1996, p. 172).

24 - Secondly, as an offspring of that "voice of immanence concerning itself" which is organic life (Jonas 1996, p. 174), the human specificity appeared and "with this, certainly, an horizon of transcendence unfolds. It becomes apparent in three freedoms of thinking that go beyond everything ascribable to matter (including the dimension of inwardness), and thus beyond all of "nature"' (Jonas 1996, p. 174). These three freedoms of thinking are: "(1) The freedom of thinking for determining itself through its choice of 
object [...]. (2) The freedom to transform the sensuously given into self-created inner images [...]. (3) The freedom, finally, carried by the symbolic wings of language, to transcend everything that can ever be said and the dimension of the sayable as such" (Jonas 1996, p. 174).

25 - Thirdly, the cosmologic evidence provided by the appearance of life and of the human being from matter leads up to a cosmogonic speculation regarding creation: "The existence of inwardness in the universe, and along with it the anthropic evidence of reason, freedom, and transcendence, are, so we have said, cosmic data. As such they belong together among the generically indispensable elements of a cosmology. Their testimony says: the universe is of the kind that such things are possible in it, perhaps even necessarily flow out of it. Does this also teach us something about its first causes, about creation?" (Jonas 1996, p. 179).

- Fourthly, Jonas' assumption about creation pivots around the question: "Can something that is less than mind be the cause of mind? We mean here the 'first' cause, the cause at the basis of all things" (Jonas 1996, p. 180), and not simply the secondary cause. Why does Jonas insist on the centrality of mind? "I speak of mind [Geist] - and this is more than life and subjectivity. For if we now assert, with a metaphor that might be permitted, that matter from the very beginning is mind asleep, so we must immediately add that the really first cause, the creative cause, of mind asleep can only be mind awake. From potential mind we must infer actual mind. This is otherwise than with living things and subjectivity as such, which, in accordance with the gradual nature of their occurrence, can indeed begin in a sleeping, unconscious manner and yet require no consciousness in the first cause, in the act of their physical birth. So the anthropic evidence, then, as part of the cosmic evidence - the self-experience of the mind, therefore, and especially its reaching out by thinking into the transcendent lead us now to the postulate of a mental, thinking, transcendent, supertemporal being at the origins of things" (Jonas 1996, p. 181).

- Fifthly, in order to clarify the cosmogonic event, Jonas proposes an "experimental and provisional" (Jonas 1966, p. 278) narration in mythical viz. conjectural terms of what occurred": "As our first proposition we say that the self-divesting of mind at the beginning was more serious than the cheerful prophet of reason [i.e. Hegel] was willing to admit. He [Mind, the deity] abandoned Himself and his destiny entirely to the outwardly exploding universe and thus to the pure chances of the possibilities contained in it under the conditions of space and time. Why He did this remains unknowable. We are allowed to speculate that it happened because only in the endless play of the finite, in the inexhaustibility of chance, in the surprises of the unplanned, and in the distress caused by mortality, can mind experience itself in the variety of its possibilities. For this the deity had to renounce His own power" (Jonas 1996, pp. 189-190). In other words, God's primeval self-negation A) creates by letting be the movement of individuation/freedom, which is characterized by natural, existential, and historical dialectics, and at the same time B) prevents Him being subject to the same dialectics (He is causa prima or primum movens of the latter, although - properly speaking - after renouncing His being, he no longer exists qua God). Thus, what Jonas seems to underline here is that God - to say it with Schelling and contrary to Hegel - is the primeval "indifference" of subjectivity and objectivity, Spirit and Nature etc. Or, to put it differently, freedom somehow precedes spirit and reason ${ }^{8}$. 
28 Finally, according to Jonas, the cosmogonic speculation has a direct impact on ethics: "God's own destiny, his doing or undoing, is at stake in this universe to whose unknowing dealings he committed his substance, and man has become the eminent repository of this supreme and every betrayable trust" (Jonas 1966, p. 274). This conjoint event calls for human responsibility, especially in times of overwhelming danger, such as the present (Jonas mentions the atomic holocaust and the ecological crisis): "the image of God is in danger as never before, and on most unequivocal, terrestrial terms. That in these terms an eternal issue is at stake together with the temporal one - this aspect of our responsibility can be our guard against the temptation of fatalistic acquiescence or the worse treason of après nous le déluge. We literally hold in our faltering hands the future of the divine adventure and must not fail Him, even if we would fail ourselves" (Jonas 1966, p. 281). Especially in times when technology can prodigiously enhance human freedom of reflection to the extent of erasing its relation to bodily constitution and the totality of reality (Becchi \& Franzini Tibaldeo 2016), ethics ought to remind us that subjectification and objectification have to be somehow re-connected: (human) subjectivity ought to find again its place in the world and to refresh its relationship with the vulnerable, perishable object of responsibility (Jonas 1984, p. 125-126).

In this article I carried out an enquiry into Hans Jonas' perspective on individuality, with the aim of clarifying its dynamic and its relevance to the comprehension of the phenomenon of life. This entailed considering the specificity of the human being's place in the world, since it is precisely through human understanding that life and individuality are explained. However, the peculiarity of Jonas' thinking is that this phenomenological approach results in an ontological and metaphysical enquiry endowed with an ethical impact: living beings are characterised by a specific modus essendi, which is individuality; the same is the case with human beings, although they reveal an additional feature - namely eidetic and reflective freedom, the full clarification of which requires a speculative and metaphysical investigation into the essence of reality as such. According to Jonas, the result of this enquiry leads back to the human being and to the recognition of its ambivalent centrality: on the one hand, technologically enhanced mankind is a menace to the future of the earthly adventure, since the latter no longer rests upon an invulnerable ground; on the other hand, the human being is the only being we know of that is endowed with the awareness and capability to care for the dynamic of individuation upon which its existence ultimately rests. The metaphysical conjecture that a 'transcendent' meaning reveals itself through the history of the cosmos, the evolution of life, and the appearance of mankind, provides effective backup to Jonas' endeavour to promote responsibility.

\section{BIBLIOGRAPHY}




\section{References}

Abe, Hiroshi (2015). «Ist die Welt sinnlos? Leibniz und Jonas», in Giornale Critico di Storia delle Idee 14 , p. 113-122.

Becchi, Paolo \& Franzini Tibaldeo, Roberto (2016). «The Vulnerability of Life in the Philosophy of Hans Jonas», in A. Masferrer \& E. García (eds.), Human Dignity of the Vulnerable in the Age of Rights. Interdisciplinary Perspectives, Dordrecht, Springer, p. 81-120.

Bonaldi, Claudio (2007). Hans Jonas e il mito. Tra orizzonte trascendentale di senso e apertura alla trascendenza, Vercelli, Mercurio.

Bonaldi, Claudio (2010). «Introduzione», in H. Jonas, Gnosi e spirito tardo-antico, Milano, Bompiani, p. V-LVI.

Bongardt, Michael (2014). «God in the World of Man: Hans Jonas' Philosophy of Religion», in J.-S. Gordon \& H. Burckhart (eds.), Global Ethics and Moral Responsibility: Hans Jonas and his Critics, Farnham, Ashgate, p. 105-126.

Fossa, Fabio (2014). Il concetto di Dio dopo Auschwitz. Hans Jonas e la gnosi, Pisa, ETS.

Franzini Tibaldeo, Roberto (2009). La rivoluzione ontologica di Hans Jonas. Uno studio sulla genesi e il significato di «Organismo e libertà», Milano-Udine, Mimesis.

Frogneux, Nathalie (2017). «Présentation», in H. Jonas, La Gnose et l'esprit de l'Antiquité tardive. «Histoire et méthodologie de la recherche», Milano-Udine, Mimesis, p. 9-156.

Halawa, Mark. A. (2011). «Editorial. "Homo Pictor" und "animal symbolicum”. Zu den Möglichkeiten und Grenzen einer philosophischen Bildanthropologie», in Image 14, p. 2-10.

Hösle, Vittorio (2001). «Ontology and Ethics in Hans Jonas», in Graduate Faculty Philosophy Journal 23,1, p. 31-50.

Hösle, Vittorio (2008). «Hans Jonas's Position in the History of German Philosophy», in H. TiroshSamuelson \& Ch. Wiese (eds.), The Legacy of Hans Jonas. Judaism and the Phenomenon of Life, LeidenBoston, Brill, p. 19-37.

Jonas, Hans (1965). Augustin und das paulinische Freiheitsproblem. Eine philosophische Studie zum pelagianischen Streit (1930), edited by J. M. Robinson, Göttingen, Vandenhoeck \& Ruprecht.

Jonas, Hans (1966). The Phenomenon of Life. Toward a Philosophical Biology, New York, Harper \& Row.

Jonas, Hans (1974). Philosophical Essays. From Ancient Creed to Technological Man, Englewood Cliffs, Prentice-Hall.

Jonas, Hans (1984). The Imperative of Responsibility. In Search of an Ethics for the Technological Age, Chicago, University of Chicago Press.

Jonas, Hans (1987). Der Gottesbegriff nach Auschwitz. Eine jüdische Stimme, Frankfurt am Main, Suhrkamp.

Jonas, Hans (1996). Mortality and Morality. A Search for the Good after Auschwitz, edited by L. Vogel, Evanston, Northwestern University Press.

Jonas, Hans (2004). «Wie können wir unsere Pflicht gegen die Nachwelt und die Erde unabhängig vom Glauben begründen?», in D. Böhler \& J. P. Brune (eds.), Orientierung und Verantwortung. Begegnungen und Auseinandersetzungen mit Hans Jonas, Würzburg, Königshausen \& Neumann, p. 71-84.

Jonas, Hans (2006). Conoscere Dio. Una sfida al pensiero, edited by C. Bonaldi, Milano, Albo Versorio. 
Jonas, Hans (2008). Memoirs, edited by Ch. Wiese, Waltham (MA), Brandeis University Press. Jonas, Hans (2010). Gnosi e spirito tardo-antico, edited by C. Bonaldi, Milano, Bompiani. Jonas, Hans (2015). Das Prinzip Verantwortung. Versuch einer Ethik für die technologische Zivilisation (1979), in Kritische Gesamtausgabe der Werke von Hans Jonas, vol. I/2, edited by D. Böhler \& B. Herrmann, Freiburg, Rombach, p. 1-420.

Jonas, Hans (2017). La Gnose et l'esprit de l'Antiquité tardive. "Histoire et méthodologie de la recherche», edited by N. Frogneux, Milano-Udine, Mimesis.

Merlan, Philip (1967). «Review of Hans Jonas' The Phenomenon of Life», in Philosophy and Phenomenological Research 28, 2, p. 277-278.

Michelini, Francesca (2020). «Philosophy of Nature», in M. Bon-

gardt, H. Burckhart, J.-S. Gordon, J. Nielsen-Sikora \& (eds.), Jonas Handbook, Stuttgart, Metzler.

Nielsen-Sikora, Jürgen (2017). «Werkzeug, Bild und Grab. Hans Jonas' Kulturtheorie und ihre ethischen Implikationen», in G. Weiß (ed.), Kulturelle Bildung. Bildende Kultur, Bielefeld, Transcript, p. 427-436.

Pinsart, Marie-Geneviève (2002). Jonas et la liberté. Dimensions théologiques, ontologiques, éthiques et politiques, Paris, Vrin.

Pommier, Éric (2013). Jonas, Paris, Les Belles Lettres.

Rasmussen, Jesper L. (2018). «Freedom as Ariadne's Thread through the Interpretation of Life: Schelling and Jonas on Philosophy of Nature as the Art of Interpretation», in Kabiri: The Official Journal of the North American Schelling Society 1, p. 69-91.

Rubio, Roberto (2014). «Hans Jonas como teórico de la imagen. Análisis crítico de la recepción de Jonas en el marco de la Bildwissenschaft», in Alter 22, p. 63-77.

Schirra, Jörg \& Sachs-Hombach, Klaus (2010), «Homo Pictor and the Linguistic Turn: Revisiting Hans Jonas' Picture Anthropology», in Linguistic and Philosophical Investigations 9, p. 144-181.

Spinelli, Emidio (2016). «Dieu, l'homme et le cosmos selon Hans Jonas. Existence et évolution», in Archives de Philosophie 79, 3, p. 539-551.

Spinelli, Emidio (2019). Obiettivo Platone: a lezione da Hans Jonas, Pisa, ETS.

Suárez Müller, Fernando (2013). «From an Existentialist God to the God of Existence. The Theological Conjectures of Hans Jonas», in Sophia 52, p. 657-672.

Theis, Robert (2014), «Hans Jonas et la question de la destination de l'homme», in Alter 22, p. 29-46.

Theis, Robert (2019), Hans Jonas. Etappen seines Denkwegs, Dordrecht, Springer.

Vogel, Lawrence (2018). «Evolution and the Meaning of Being: Heidegger, Jonas and Nihilism», in Continental Philosophy Review 51, p. 65-79.

\section{NOTES}

1. Jonas 1974, p. 196. See also Jonas 1966, p. 90-91, 106. See Becchi \& Franzini Tibaldeo, 2016, p. 94.

2. See Jonas 1966 , p. 7-26. See also Jonas 1996, p. 167-170. Recently Lawrence Vogel (2018) has devoted some effort to clarifying further this aspect of Jonas' philosophy. 
3. Some scholars dealing with Jonas' account of the anthropological specificity (Pommier 2013, p. 75-86; J. Nielsen-Sikora 2017) have focused on the essay 'Werkzeug, Bild und Grab' (English translation in Jonas 1996, p. 75-86) rather than on The Phenomenon of Life (chapter seventh: 'Image-making and the Freedom of Man' [Jonas 1966, p. 157-182] and the 'Transition: From Philosophy of the Organism to the Philosophy of Man' [Jonas 1966, p. 183-187]). Others (Schirra \& Sachs-Hombach 2010; Halawa 2011) have tried to use Jonas' anthropology in order to clarify the relationship between image faculty and language. As a result, these scholars have either overlooked or misunderstood the twofoldness of Jonas' anthropological account and the relationship between image faculty and (self-)reflection. Whereas others (Rubio 2014) seem to have accomplished a more convincing interpretation of these issues.

4. See Jonas 1965; Jonas 1996, p. 177; Jonas 2006; Jonas 2010; Jonas 2017. See also Bonaldi 2010; Bongardt 2014; Frogneux 2017.

5. Jonas 1996, p. 171-172. For Jonas' ontological revision of the notion of matter (Jonas 1966, p. 81; Jonas 2008, p. 222), see especially Franzini Tibaldeo 2009; Theis 2014, p. 34-39; Spinelli 2016, p. 541-542. See also Abe 2015; Spinelli 2019; Theis 2019.

6. For instance, Marie-Geneviève Pinsart's (2002) in-depth enquiry into the thinking of Hans Jonas begins with his speculative theology, which she sees as providing the metaphysical foundation of his philosophy of freedom, his phenomenology of life, and his ethics. Like Robert Theis (2014), I choose instead the opposite hermeneutical path, beginning with Jonas' phenomenology of life and ending with his theological-metaphysical and ethical enquiry. For this there are two main reasons: A) it is indeed Jonas' aim to go beyond traditional viz. foundational and static accounts of ontology by benefitting from his "ontological revolution" (Jonas 1966, p. 81; Jonas 2008, p. 222; Franzini Tibaldeo 2009; Theis, 2014) ; B) to assume that Jonas' speculative theology provides the metaphysical foundation of his thinking is in some way misleading, since Jonas' philosophical reflection does not ultimately rely on religion (see for instance Jonas 2004), nor can he be classified as a religious thinker, although he does reappraise tradition by making a philosophical use of religious concepts (Theis, 2014, p. 46; Spinelli 2016; Vogel, 2018).

7. Robert Theis (2014, p. 46) underlines correctly that Jonas' use of myth (even when it concerns ultimate issues, such as creation and God) remains strictly within the boundaries of philosophy, and never gives rise to a religious belief. Jonas conceived of the myth of the impotent God in the 1960s and in the following decades published several modified versions of it (see for instance Jonas 1966, p. 275-277, and Jonas 1996, pp. 189-191, which are relevant to the current enquiry; see also the well-known Der Gottesbegriff nach Auschwitz. Eine jüdische Stimme [Jonas 1987]). Some scholars, especially Claudio Bonaldi (2007) and Fabio Fossa (2014), have carefully analysed the evolution of Jonas' thinking in this regard. See also Spinelli 2016 and Theis 2019, p. 51-56.

8. In one of the first reviews of Jonas' The Phenomenon of Life ever published Philipp Merlan acknowledged that "Jonas might have been interested in Schelling's version of the 'becoming God"' (Merlan 1967, p. 278). More recently Fernando Suárez Müller (2013, p. 668) refers to the same idea, which might have helped Jonas develop an alternative to a Hegelian perspective on theology. However, I do not agree with Suárez Müller's strictly intellectualistic analysis and criticism of Jonas' impotent God (Suárez Müller 2013, p. 669). On the similarities between Schelling and Jonas, see Rasmussen, 2018 and Michelini 2020. As a result, I disagree with the interpretation proposed by Vittorio Hösle (2001 and 2008), according to which Jonas' thinking belongs itself "to the tradition of objective idealism" (Hösle 2001, p. 42) in that it ultimately supports the anteriority of Geist or reason to freedom (Hösle 2001, p. 47). 